\title{
Negotiated Government in Zimbabwe-Tool for Peaceful Co-existence or Momentary Suppression of Inherent Divisions?
}

\author{
Ms Petra Chinyere
}

Mulungushi University, Zambia

rumbicc@gmail.com

\section{Doi:10.5901/mjss.2014.v5n25p73}

\begin{abstract}
This paper assesses the effectiveness of the Government of National Unity (GNU) in Zimbabwe in fostering peaceful coexistence among traditional rival political parties which were the parties to the agreement that established the unity government. It is mainly based on documentary research, referring to available information on the four year period that the GNU ruled the country, followed up by some views from fellow academics on the subject. The point of departure is the historical background to the formation of the GNU and the modalities surrounding its establishment, then the analysis of what really achieved. The paper argues that the GNU was an inevitable arrangement that was done as a transitional mechanism to rescue the country from total collapse after the 2008 electoral violence that the country had plunged into which could have degenerated into a civil war. The GNU managed to sustain the peace deal that they signed and to calm the political situation in the country to give a peaceful environment even after its lifespan among the parties that fought in 2008, but it brought to the fore the concealed, inherent divisions and intra-party fighting that the Movement for Democratic Change Tsvangirai faction (MDC-T) has been accused of previously. The paper concludes by arguing that the GNU deal was successful in achieving peaceful co-existence among warring factions along the political divide but it still failed to take into consideration the views of the masses since it was an elite contract.
\end{abstract}

Keywords; Negotiated Government, GNU in Zimbabwe, Peaceful Co-existence, SADC Mediation, GNU term.

\section{Introduction}

The GNU in Zimbabwe reigned between February 2009 and July 2013 after the Southern African Development Community (SADC) initiated, South African led negotiations managed to broker a peace deal. The 2008 harmonised elections were generally peaceful after being held within the context of political negotiations between the Zimbabwe African National Union Patriotic Front (ZANU PF) and the two MDC formations. ${ }^{1}$ However, events after the release of results for Parliamentary and Council elections and the subsequent loss of ZANU PF majority in parliament led to serious fighting among political parties mainly ZANU PF and MDC-T. The state of affairs in Zimbabwe at that time paused a serious threat to the well being of most citizens to a point where the international community pressured regional groupings to act, resulting in the SADC re-engagement on the Zimbabwe crisis. ${ }^{2}$ The negotiations managed to broker a peace deal and the parties entered into a marriage that restored peace in the country and brought back the much needed, economic revival to an ailing economy. In as much as peace and economic vibrancy was achieved the deal was allegedly just a thick veil behind which a lot of uncertainties lay. This paper investigates whether the negotiated government indeed achieved peace or it was a moment of the suppression of the inherent divisions and rivalry among the opposing groups.

\subsection{Background}

Zimbabwe has historically been a 'one party state', with the ZANU-PF being the main player in the politics of the nation. Since independence, the opposition political parties that mushroomed were either co-opted or rendered irrelevant by events. In 1987 for example, the main opposition political party, Patriotic Front - Zimbabwe African People's Union (PF-

${ }^{1}$ Eldred Masunungure (ed) (2009) Defying the Winds of Change: Zimbabwe's 2008 Elections Weaver Press and Konrad Adenauer Foundation Harare. p. 62.

${ }^{2}$ Eldred Masunungure (2009) Zimbabwe Power Sharing Agreement Paper Presented at a workshop on The Consequences of Political Inclusion in Africa April 24-25, American University, Washington DC. p. 4. 
ZAPU) was assimilated into the main wing Zimbabwe African National Union (ZANU) party to form ZANU PF which led to Zimbabwe becoming a de facto one party regime. ${ }^{3}$ The formation of the MDC in 1999, marked the beginning of a new era where there was intensified electoral violence in Zimbabwe, intensified tension among parties, victimisation of opposition members and government critics, infighting within political parties, repressive legislation and allegations of vote rigging among other political ills. Sachikonye L. pointed out that, "what changes from 2000 onwards are the scale, intensity and militarization of the violence," ${ }^{4}$ presenting his argument that electoral violence has always been there since independence. The political playing field since then has been tilted in favour of the ZANU PF party as allegations of vote rigging have been levelled against the party. The political landscape in the country led to the souring relations with the outside world, particularly the former colonial master mainly after the bloody farm invasions of 2000. This saw the imposition of sanctions on some government officials and their families which some claimed affected only the targeted members yet a closer look points to the suffering of the whole country as a result of the sanctions, for instance government enterprises like Zimbabwe Mining Development Cooperation (ZMDC) were put under sanctions. Resultantly there was serious economic meltdown, giving rise to a new monetary regime with bearers' cheques among other improvisions in a bid to rescue the economy which faced serious hyper inflation. The situation in the country deteriorated and worsened by the day, economically, socially, and more so politically.

Zimbabwe witnessed the bloodiest elections in the June 2008 Presidential run-off. ${ }^{5}$ There were 107 cases of murder recorded by the Zimbabwe Human Rights NGO Forum ${ }^{6}$ and a lot more injuries, displacement, damage to property, theft especially stock theft among other social ills. This resulted in a public outcry that drew international attention. The SADC efforts to resolve the crisis resulted in the negotiation that saw the birth of the GNU which is, as pointed out earlier, the main focus of this paper.

\subsection{Conceptual Framework}

\subsubsection{Negotiated Government}

In a normal democratic set up, a government is chosen by the citizens through a free, fair and participatory election process. A negotiated government on the opposite end, is a government that comes into being when opposing or competing factions in a nation fail to hold a free, fair and participatory election process resulting in disputed elections that may lead to an undeclared state of war like in the case of Zimbabwe where the GNU was established after disputed elections. " "Largely, these are emerging out of hot political contestations depicting high levels of violence and tense fragmentation of society." 8 The warring factions eventually through mediation or intervention may come to the negotiating table to resolve their differences. If a deal is successfully brokered then a negotiated settlement may lead to the formation of a negotiated government. Eanglemore quoted by Mapuva holds that "...GNUs are seen as a transitional measure, a vehicle to reduce tension and to create space to drive durable peace and sustainable change."9

\subsubsection{GNU in Zimbabwe}

The 2008 political tension and fighting among opposing parties, resulted in bloodshed that required action. As a result, the SADC mediation managed to broker a deal between the main opposing parties. This deal culminated in the signing of the GPA in September 2008 and the subsequent formation of the GNU in February 2009 as a framework for addressing

\footnotetext{
${ }^{3}$ Samuel Maruta et al (2013) A Review of Zimbabwe's Global Political Agreement (GPA) Southern Peace Review Journal Volume 2 Number 1, Southern Institute of Peace-Building and Development, Harare. p. 5.

${ }^{4}$ Lloyd Sachikonye (2011) When a State Turns on its Citizens: Institutionalised Violence and Political Culture, Jacana Media, Sunnyside. p. 18.

${ }^{5}$ Eldrad V. Masunungure (2009) Defying the Winds of Change: Zimbabwe's 2008 Elections, Weaver Press and Konrad Adenauer Stiftung, Harare. p. 61.

${ }^{6}$ Lloyd Sachikonye (2011) When a State Turns on its Citizens: Institutionalised Violence and Political Culture, Jacana Media, Sunnyside. p. 21.

7 Jephias Mapuva (2013) Government of National Unity (GNUs) and the Preponderance of the Incumbency: Case of Kenya and Zimbabwe International Journal of Political Science and Development Volume 1 (3). p. 105.

\& Percyslage Chigora and Tobias Guzura (2011) The Politics of the Government of National Unity (GNU) and Power Sharing in Zimbabwe: challenges and Prospects for Democracy, African Journal of History and Culture(AJHC), Vol.3 (2), p. 20.

9 Jephias Mapuva (2013) Governments of National Unity (GNU) and the Preponderance of the Incumbency: case of Kenya and Zimbabwe, International Journal of Political Science and Development, Volume 1 (3) of November 2013. p. 106. 
the crisis and map a better future for the nation. ${ }^{10}$ In the preamble of the GPA, the parties to the agreement, dedicated themselves to putting an end to the polarisation, divisions, conflict and intolerance that had been a feature of Zimbabwean politics. The power sharing deal saw the sharing of government posts among the three political parties with ZANU PF getting the highest number and some key ministries. The political marriage that existed among these three parties was allegedly a marriage of convenience that had serious power imbalances, tilted mainly to benefit the incumbent leader and in a way the principals, not the general people at large. These parties had nothing at all in common when it came to ideology. ${ }^{11}$

The political stalemate that existed after the flawed elections led to a legitimacy crisis within the ZANU PF camp as they were not recognised by most governments world over and disgruntlement in the MDC camp who insisted that Tsvangirai had not been defeated since he had pulled out of the race so to them the run-off was a non-event. Intensifying tension created an atmosphere conducive for negotiations to broker a deal for a unity government. "The African Union and SADC intervened and brokered a power-sharing arrangement between ZANU PF and the two MDC formations. According to the AU, that was an African solution to an African problem."12 The Global Political Agreement (GPA) spelt out all the modalities that were going to guide this new arrangement which was going to be a transitional measure to help reduce tension and create the space to drive durable peace and sustainable change, ${ }^{13}$ according to Eanglemore.

The GNU lasted for 4 years, its term coming to an end in July 2013 when the country went to the polls in which ZANU PF won resoundingly. The GNU therefore acted as a transitory government as the leaders were bent on restoring democracy in the country and economic revival for the benefit of the whole nation, although some view it as a factor contributing to the erosion of democracy. During its existence the GNU managed to bring some remarkable changes especially to the economy; for instance multi currency regime, economic growth and arresting the hyperinflationary environment and restoring investor confidence although the parties suspected each other of insincerity.

\subsubsection{Inherent Divisions}

Peace generally refers to absence of war. The democratic peace theory takes peace to be reluctance for war mainly due to the necessity of avoiding economic collapse. The looming political tension in Zimbabwe in 2008 could have easily degenerated into civil strife had the negotiations failed to obtain a peace deal. The parties to the GPA and subsequently GNU, were declared rival groups since the formation of the MDC in 1999 and could not agree much on anything as evidenced by the arguments and disagreements in parliament since 2002. The political playing field has been allegedly uneven, riddled with violent clashes and tensions. The post 2000 elections have witnessed serious clashes between different political party supporters with the blessing of their leaders in most cases. Violence in Zimbabwe, might have a long history since the liberation struggle but the intensity has been on the increase especially in the post 2000 era as ZANU PF hegemony faced its first serious challenge since independence posed by the MDC. There have been opposition parties coming on the political scene, among them Zimbabwe Unity Movement (ZUM) in 1990, the Forum Party in 1993 and Zimbabwe Union of Democrats (ZUD) in 1998 but have not really presented a challenge to Robert Mugabe and his party like the MDC challenge did. The Tsvangirai led, labour movement born, MDC has been the worst nightmare that ZANU PF has had to deal with since its coming into power in 1980. The unprecedented challenge led to the then ruling party ZANU PF devising ways of dealing with the new party among them demonising its leaders, labelling them white or British puppets, ZANU PF

Have always defended their misgivings on the MDC's involvement with the West by alluding to the fact that many people lost their lives fighting to liberate Zimbabwe from the yoke of colonialism and that history has taught them how the imperialists would always want to come back through the back door.... ${ }^{14}$

There has therefore been a reign of terror unleashed against MDC party leadership and supporters alike with the aim of intimidating them. Robert Mugabe has always maintained that Morgan Tsvangirai is not suitable for the highest

${ }^{10}$ Samuel Maruta (2013) et al A Review of Zimbabwe's Global Political Agreement (GPA) Southern Peace Review Journal Volume 2 Number 1 Southern Institute of Peace-Building and Development. p. 8.

11 Percyslage Chigora and Tobias Guzura (2011) The Politics of the Government of National Unity (GNU) and Power Sharing in Zimbabwe: Challenges and Prospects for Democracy, African Journal of History and Culture (AJHC).p. 23.

12 T Nhede (2012) The Government of National Unity in Zimbabwe: Challenges and Obstacles to Public Administration, African Journal of Public Affairs, Volume 5 Number 3. p. 180.

13 Jephias Mapuva (2013) Governments of National Unity (GNUs) and the Preponderance of the Incumbency: case of Kenya and Zimbabwe International Journal of Political Science and Development Volume 1 (3).p. 106.

${ }^{14}$ N. T Nhede (2012) The Government of National Unity in Zimbabwe: Challenges and Obstacles to Public Administration, African Journal of Public Affairs Volume 5 Number 3 p. 185. 
office in the country, mainly because of the political blunders made in the past, for instance openly denouncing the role that the freedom fighters played in liberating the country from colonial rule yet he did not himself participate in the liberation struggle and choosing to align with the Western world at the expense of Regional groups. Thabo Mbeki is said to have pointed this Western allegiance to Morgan Tsvangirai in a letter noting that,

Realistically, Zimbabwe will never share the same neighbourhood with the countries of Western Europe and North America and therefore secure its success on the basis of friendship with these...... It may be that, for whatever reason, you (Tsvangirai) consider our region and continent as being of little consequence for the future of Zimbabwe, believing that others further away, in Western Europe and North America are of greater importance..$^{15}$

All this coupled with personality differences characterised the relations between the two main political parties in Zimbabwe in the post 2000 era.

These same parties ironically became the chief negotiating parties to the GPA deal and the two leaders being the main players of the Principals triangle. Having such differences and the different approaches both used within their party setup made the GPA negotiations complicated and the public looked at it with scepticism. The tensions and deadlocks that were experienced in the GNU period testified to these inherent differences. These deadlocks made many question the motive these leaders had in negotiating a settlement in the first place and most if not all sceptics concluded that it was for personal reasons more than for national reasons. On one hand there was an incumbent trying to save his face and holding on to power while on the other hand a failed leader wanted to taste power even though he had very little of it. "The GPA and its many challenges was the product of a convergence of factors, namely: the unwillingness of a party of liberation to accept electoral defeat, the inability of the opposition to claim state power due to the militarisation of the ruling party's response....."16 and also "in view of Mugabe's powers, Tsvangirai may thus find himself exercising day-today supervision over ministers who have little interest in paying any heed to his instructions." ${ }^{17}$ The MDC leader joined the deal for the gravy more than for national interest since he did not have any power as pointed out. Having said that the question on whether the GNU worked as a tool for peaceful co-existence or it just momentarily suppressed these inherent differences, remains to be answered as the investigation into the actual GNU functioning is done.

\section{State of Affairs Before the Negotiated Government}

Zimbabwe has traditionally been a one party state dominated by the ZAN PF led government, since independence using different tactics to maintain its hegemony. The March 2008 elections were conducted within the scope of electoral reform brought about by the adoption of the SADC Principles and Guidelines for Conducting Democratic Elections ${ }^{18}$ and Constitutional Amendment 18 which provided for the harmonisation of elections. ${ }^{19}$ The March 2008 elections therefore combined the elections for Councillors, Members of Parliament, Senators and the President. The council, and parliamentary polls were held on a First Past The Post (FPTP) basis where whoever got the highest number of votes got the seat while the Presidential poll was on the majoritarian basis where the winner had to get $50 \%+1$ vote. Results for the council and parliamentary elections were announced as they trickled in from the poll centres ${ }^{20}$ as per electoral reform but presidential poll results took forever to be made public. John Makumbe quoted the Zimbabwe Independent saying that the results were eventually announced 5 weeks after polls and it was alleged that they were withheld on the instructions of Mugabe..$^{21}$ The Presidential candidates failed to get the required threshold and as such there was a run-off election set for June 2008. There were clashes between members of the ZANU PF and the MDC-T as the presidential

\footnotetext{
${ }^{15}$ Derek Matyszak (2010) Law, Politics and Zimbabwe's 'Unity' Government Konrad Adenauer Stiftung and the Research and Advocacy Unit, Harare. p. 1.

${ }^{16}$ Brian Raftopoulos (ed) (2013) The Hard Road to Reform: The Politics of Zimbabwe's Global Political Agreement Weaver Press and Solidarity Peace Trust, Harare. p. 28.

${ }^{17}$ Derek Matyszak (2010) Law, Politics and Zimbabwe's 'Unity' Government Konrad Adenauer Stiftung and the Research and Advocacy Unit, Harare p. 72.

${ }_{18}$ Zimbabwe was the first country to implement the SADC Principles and Guidelines for Conducting Democratic elections which mainly brought about electoral reforms meant to make elections more credible. The Constitutional Amendment number 18 also brought in changes related to elections mainly increasing the number of parliamentary seats.

${ }^{19}$ Eldrad Masunungure (ed) (2009) Defying the Winds of Change: Zimbabwe's 2008 Elections Weaver Press and Konrad Adenauer Foundation, Harare. p. 61.

${ }^{20}$ Samuel Maruta (2013) A Review of Zimbabwe's Global Political Agreement (GPA) Southern Peace Review Journal Volume 2 Number 1, Southern Institute of Peace-Building and Development, Harare. p. 7.

${ }^{21}$ Eldrad Masunungure (ed) (2009) Defying the Winds of Change: Zimbabwe's 2008 Elections Weaver Press and Konrad Adenauer Foundation, Harare. p. 128.
} 
results delayed since there was speculation that the results delayed because the MDC-T candidate Morgan Tsvangirai had won the election and ZANU PF as the party in charge of the electoral system manipulated the results. Quoting the Zimbabwe Independent John Makumbe noted that, the results were withheld on the instructions of Mugabe and the Zimbabwe Electoral Commission (ZEC) complied since they were at the disposal of Mugabe mainly because he appoints ZEC officials. ${ }^{22}$ This resulted in violent clashes that cost so many lives and worsened when the announcement of the runoff election was made. Many were displaced, maimed, murdered, abused and terrorised as the uniformed forces embarked on 'Operation Makavotera Papi?' (Operation which party did you vote for?) which was basically to uproot those who had voted for or supported the $\mathrm{MDC}^{23}$, with most people deserting their homes for fear of falling victim to that operation. These clashes resulted in the MDC candidate pulling out of the run-off race and letting it be a one man show which was devoid of credibility. The run-off elections were widely dismissed as a non-event and this led to the legitimacy crisis that Mugabe faced after the election when he was sworn in as the new President, which forced him to return to the negotiating table.

....the run-off presidential election of 27 June did not reflect the will of the people. This created a crisis of legitimacy for Mugabe and an embarrassing difficulty for SADC. Botswana unequivocally refused to recognise Mugabe ad head of state, and even the Mbeki-led government of South Africa, noted within Zimbabwe for its support for Mugabe, prevaricated. ${ }^{24}$

\subsection{Electoral Violence}

The March 2008 elections were regarded as relatively peaceful since they were held within the scope of electoral reforms, SADC Principles and Guidelines for Democratic Elections and negotiations among the main parties. The unexpected outcome of the March 2008 elections, as results were announced upon submission, resulted in the withholding of the presidential results for 5 weeks. As the wait for the results continued, tension increased and violent clashes resulted among opposing forces in the country, worsened by the fact that ZANU PF had lost its majority in parliament. There was an undeclared state of emergency where most parts of the country experienced unofficial curfew. In some parts, particularly rural areas, ZANU PF youths used to chant slogans and sing 'Chimurenga songs' around dawn and dusk allegedly declaring the beginning and end of the unofficial curfew because people would not be seen outside during the curfew hours for fear of being forced to join the ZANU PF militia. Families locked up their children of the youth age group for fear of having them recruited into the youth militia that terrorised villages and extorted people's money, animals and fowls for their upkeep. Most people lost their property as they were forced to contribute to food in the camp areas and some had their homes torched being accused of having voted wrongly in the March elections. Many lives were lost, limbs cut off and untold suffering especially for women, some of whom were raped, as a war tactic, and lost their husbands who were bread winners and in some cases losing their children. The clashes were very costly on the population mainly in rural areas. People disappeared and some relocated for fear of their lives. The prolonged waiting for the presidential results made the violence even worse. The results were eventually announced and the fact that there was no clear winner made the situation unbearable as ZANU PF supporters ensured that they intimidate the MDC supporters and force them into, either not going to vote at all or voting for ZANU PF. The brutal campaign instigated by Mugabe's supporters to reverse his electoral defeat in the 29 march presidential election resulted in a Pyrrhic victory. ${ }^{25}$ The violent clashes continued for close to a month until the decision by the MDC candidate Morgan Tsvangirai to pull out of the race citing violence as the reason for pulling out since he did not intent to have more supporters lose their lives at the hands of the ZANU PF party. In rural areas people were maimed and killed mercilessly, leaving most communities terrorised and families scattered all over.

\subsection{Run-off Period}

The announcement of the run-off election between the two candidates with the highest votes, Robert Mugabe and

22 Ibid p. 128.

${ }^{23}$ Llyod Sachikonye (2011) When a State Turns on its Citizens: Institutionalised Violence and Political Culture Jacana Media, Auckland Park. p. 49 .

${ }^{24}$ Derek Matyszak (2010) Law, Politics and Zimbabwe's 'Unity' Government Konrad Adenauer Stiftung and the Research and Advocacy Unit, Harare. p. 66.

${ }^{25}$ Derek Matyszak (2010) Law, Politics and Zimbabwe's 'Unity' Government Konrad Adenauer Stiftung and the Research and Advocacy Unit, Harare. p. 66 . 
Morgan Tsvangirai, meant intensification of terror attacks by supporters of both parties as mentioned earlier. Bombing attacks and infliction of terror in the name of retortions by MDC cadres for alleged omissions and commissions by the police force and ZANU PF supporters were carried out. On the other hand MDC cadres were killed, houses torched and livestock stolen; for instance the bombing of Jerera MDC offices which resulted in the death of one person and disability for two others. The pre- runoff period was marred by violence resulting in regional and international concerns being raised over the security of ordinary Zimbabweans. The withdrawal of the MDC candidate rendered the whole run-off idea irrelevant and futile as people ended up having to vote for one person without considering the expense that was incurred by the nation in putting in place all the requirements for an election to be held. There were rumours that the American and British governments had set up a base in Botswana waiting to intervene in the country had a civil war broke out. Most people went to the poll just to clear their names especially in rural areas, particularly after the 'Operation makavhotera papi' that had been undertaken in between the two polls. Without considering how they were going to vote, with one candidate up for election, eligible voters had to be seen to be voting to avoid being labelled deviants since it had consequences going with such deviance. The ZANU PF candidate, the only contestant then was later announced as the winner of the race and immediately sworn in as the President of the Republic against all odds. The fact that the election had been dismissed by many meant that the results did not receive any recognition from the outside world even in the region which had always stood by the nationalist party. "Violating all democratic requirements for a free and fair election, even the ZANU PF government's invited observers .....were constrained to report that the run-off presidential election of 27 June did not reflect the will of the people."26

This non recognition of the election results led to a serious legitimacy crisis that forced the declared president to the negotiating table.

\subsection{Post Run-Off Scenario}

After the runoff results, the swearing in and officially having a new government in place, the situation in Zimbabwe worsened, in terms of economic hardships and political tension. Violence continued in most parts of the country and the economy continued to deteriorate. The fact that one candidate pulled out of the runoff race, though legally late, discredited the process and it was made worse by the terror campaign that was widespread allegedly perpetrated by the ZANU PF cadres in support of the same candidate in order to reverse the March defeat. All this made states all over refuse to recognise the new government as witnessed by the turn out at the swearing in ceremony.

The economy of Zimbabwe started deteriorating in the post 2000 era with the enactment of different acts and policies that were detrimental to the country. These included the land reform programme, closure of foreign currency exchange bureaus, continued printing of money by the reserve bank, enactment of the Access to Information and Protection of Privacy Act (AIPPA), Public Order and Security Act (POSA) and the militarisation of most government departments. These policies contributed to the economic meltdown that reduced Zimbabwe from the bread basket of SADC to a basket case in the SADC region. The Zimbabwean dollar continued to drop value drastically and it led to mushrooming of money changers throughout the country and money laundering was common in most banks. The Reserve bank introduced monetary policy reviews every quarter that turned things around in most cases disrupting the smooth play of economic forces in the country. Most shops were empty and grocery items were imported from neighbouring countries which left ordinary people worse off since they could not afford the exorbitant prices charged, worsened by the shortage of local currency that made the foreign currency unaffordable for most people. In rural areas some people died from starvation and diseases as they could not afford basic commodities worse still accessing medical facilities. Hospitals did not have drugs let alone be affordable to the public. The economic crisis was argued by Eustinah Tarisayi to be a result of economic sanctions by the West and also a result of withdrawal of financial aid, suspension aid flows by the West. ${ }^{27}$

\section{GNU Term}

The GNU ruled Zimbabwe between February 2009 and May 2013. It lasted for 4 years and it had its own successes and failures related to the issue of fostering peace, democracy and co-existence. The impasse, violence and tension of the

${ }^{26}$ Derek Matyszak (2010) Law, Politics and Zimbabwe's 'Unity' Government Konrad Adenauer Stiftung and the Research and Advocacy Unit, Harare. p. 66.

${ }^{27}$ Eldred Masunungure (2009) Defying the Winds of Change: Zimbabwe's 2008 Elections Konrad Adenauer Foundation and Weaver Press Harare. p.14-15. 
pre and post 2008 elections resulted in increased international concern that led to the SADC mediation led by South African President Thabo Mbeki to try and bring peace. The negotiating teams constituted of representatives from the three main political parties. The allocation of posts in the new government was dependent on the representation in Parliament where ZANU PF had 98 seats, MDC-T 99 seats while MDC-M had 10 seats. The Principals were the main actors in the negotiations but they were not directly involved in the actual negotiations, they were only consulted by their negotiating teams. The Principals were the leaders of the three parties, Robert Mugabe for ZANU PF, Morgan Tsvangirai for MDC-T and Arthur Mutambara for MDC-M. The principals had the final say on any contentious issues that came out of the negotiation process so they were consulted at every step of the process by their teams.

These negotiating teams presented the arguments from the view points of their different 'parties' if not party leaders only since none of the parties ever consulted their supporters. It is alleged that the leaders engaged in an elite negotiation, neglecting the priorities and views of the general public thereby compromising on democratic choice. The GNU was more of an imposition on the general people, an elite creation meant to meet the leaders' own interests; on one hand the interest being to hold on to power while on the other being to have a chance to taste the sweetness of power.

\subsection{GPA Negotiation}

The power-sharing negotiations were viewed differently by the respective parties. The MDC intended to make it an opportunity to restore 'democracy' while ZANU PF did not think along those lines. "While the power-sharing arrangement .....was uppermost in many people's minds at this point, the MDC leader Morgan Tsvangirai, said of the post-election negotiations, 'This is not about power-sharing. It is about a return to democracy.' Thus Phrased Mbeki was faced with an intractable problem." 28 The main issues however, that they addressed were to do with power sharing and the particular ministries that each party was going to occupy. The main ministries that were contentious were Home Affairs, Finance and Defence. The Presidential and Prime Ministerial powers were also the other issue that brought a lot of debate and serious negotiations. The previous setup in Zimbabwe, where there was a President and Prime Minister was that the President was ceremonial while the Prime Minister was executive, implying that the Prime Minister had more powers than the President, during the early years of independence under the Presidency of $\mathrm{C}$. S Banana. The assumption during the GNU was that they will go the same way, where the Prime Minister was going to be Executive while the President was Ceremonial. That expectation was not met as the GNU set up dictated that the President remains executive while the Prime Minister was ceremonial, which raised a lot of eyebrows from the public who felt cheated by the marriage. It was noted that Mugabe had not conceded any power in the GNU arrangement. The only concession he had made in exchange for the retention of his extensive powers and recognition of his legitimacy.......... the lessening of his powers of patronage by the reduction in the number of ministerial posts he could allocate."29 Most people expected the MDC to have rejected the offers on the table since the Presidential office went to the ZANU PF in full while the two MDC camps were made to share the Prime Minister's office.

These negotiating teams presented the arguments from the viewpoints of their different 'parties', if not party leaders only since none ever did any consultation with their supporters. It is alleged that the leaders engaged in an elite negotiation neglecting the priorities and views of the general public thereby compromising on democratic choice. The GNU was more of an imposition on the general people, an elite creation meant to meet their own interests; one being to hold on to power and the other to have a chance to taste the sweetness of power. The negotiations were marked with episodes of serious tension as parties failed to agree on some of the issues they were discussing.

\subsection{GNU setup}

The negotiations ended in the sharing of the 31ministerial posts by the three parties to the GPA, as follows; ZANU PF 15posts, MDC-T 13 posts and MDC-M 3 posts. ${ }^{30}$ The main contentious ministries were the Finance, Home Affairs, Information and Publicity and Defence Ministries. "Mugabe divided the portfolios between ZANU PF and the MDC as the

${ }^{28}$ Derek Matyszak (2010) Law, Democracy and Zimbabwe's 'Unity' Government Konrad Adenauer Stiftung and the Research and Advocacy Unit, Harare. p. 66.

${ }^{29}$ Ibid p.67.

${ }^{30}$ Eldred Masunungure (2009) Zimbabwe's Power Sharing Agreement Paper Presented at a workshop on "The Consequences of Political Inclusion in Africa" America University, Washington D.C. p. 7. 
agreement required, but allotted what are considered to be key portfolios exclusively to ZANU PF ...." ${ }^{11}$ ZANU PF took Defence and Information and Publicity while the MDC-T took Finance then they co-ministered Home Affairs. In as much as they shared these ministries, it was alleged that MDC-T and MDC-M ministers were just playing second fiddle to Permanent Secretaries within the respective ministries. That also raised the question of whether the marriage was on equal basis or one party was more equal than the rest.

\subsection{Deadlock and challenges}

The parties to the GNU agreed on the need for them to work together for nation building but they disagreed on approaches most of the time. In as much as the MDC controlled the Finance ministry, they did not know much about the financial status of the country, witnessed by the several instances where the Finance Minister announced the bankruptcy of government and how they were not in a position to pay civil servants, yet the civil servants will get their salary at the end of the month. Such actions clearly pointed to the disjointed nature of the government. There were also allegations especially in the co-ministered Home Affairs that one party did not have any say and in the first place just the idea of sharing a Ministry did not quite satisfy the general people. The deadlock over the allocation of ministerial posts led to Mugabe showing his extensive powers by unilaterally allocating ministerial posts without consulting any other Principal as required by the agreement. ${ }^{32}$ Most supporters were surprised that Morgan Tsvangirai had signed an agreement that left Mugabe's powers unfettered. The President was given power to hire and fire ministers when they fail to perform their duties, in consultation with the leaders of the MDC formations. Tsvangirai's position in government was little more than window dressing since he did not have much say. ${ }^{33}$ The GNU therefore had serious power imbalances that reduced the setup to a mere ZANU PF mechanism to gain legitimacy and revive the sour relations with the world that had cost the nation seriously.

\section{Post- GNU Period}

\subsection{ZANU-PF scenario}

The 2013 elections that marked the end of the GNU set up, saw ZANU PF getting the majority of the elected seats in parliament and forming government on its own. The party had been riddled with succession issues that threatened to disintegrate the party at some point in its history but the leader managed to keep such differences within check and thwart any threat to its unity, although the divisions are still reportedly there. For instance while giving his closing remarks at the $6^{\text {th }}$ ZANU PF National Women's conference in 2014, President Mugabe noted that some men will remain divided, leading factions but women had chosen to be one..$^{34}$ There was the 'Baba Jukwa' fiasco, a Facebook figure who has been spilling high profile classified ZANU PF news resulting in investigations that led to the arrest of Edmund Kudzai, The Sunday Mail editor on accusations of being the anonymous character. It is also rocked with allegations of factions trying to win the President's heart by backing Grace Mugabe, the first lady, for the post of Secretary for Women's Affairs at the next party congress in December 2014.

After forming their new government, there was the coming into the scene of new players, the likes of Lazarus Dokora, the Minister of Education, Sports and Culture with their overzealous nature and controversial statements that have sparked some tension within the education setup especially concerning staff welfare and reversal of some pronouncements made earlier, for instance the issue of holiday and extra classes for students which had been stopped but are currently tipped to continue. The appointment of ministers also saw some reshuffling of controversial Ministers like Saviour Kasukuwere, from the Youth ministry where he introduced the Empowerment policy which was riddled with serious allegations of corruption and embezzlement of funds. In as much as the ZANU PF government managed to form a new government, they still face serious challenges in reviving the economy since it is still ailing, now on a deflationary scale. On the positive end however Mugabe managed to get the SADC Chair post although most people question if he will manage at an advanced age like his, time will show the ability.

${ }^{31}$ Derek Matyszak (2010) Law, Politics and Zimbabwe's Unity Government Konrad Adenauer Stiftung and the Research and Advocacy Unit, Harare. p.67.

32 Derek Matyszak (2010) Law, Politics and Zimbabwe's 'Unity' Government Konrad Adenauer Stiftung and the Research and Advocacy

Unit, Harare. p. 68.

${ }^{3}$ Ibid p. 68-72.

${ }^{34}$ The Sunday Mail 17 August 2014 Women Refuse to Listen to Evil Machinations: President. 


\subsection{MDC-T Scenario}

After getting only 49 seats in the 2013 elections, the MDC in-house differences came to a boiling point and could no longer be swept under the carpet. There was a major leadership crisis that some felt had to be resolved since the party had lost dismally to ZANU PF, getting 49 Parliamentary seats out of the 210 elected ones. The MDC Presidential candidate, Morgan Tsvangirai managed to get only $31 \%$ of the vote which did not go down well with some of the party leadership who felt it was time to change the party leader since he had lost relevance after losing since the inception of the MDC. Since 2013, the leadership of Morgan Tsvangirai came under scrutiny by members of his council which included; Roy Bennett, the Treasurer General, questioned his continued stay after successive loss, lan Kay one of his staunch supporters, Elias Mudzuri, former Organising Secretary and the most contentious being from Elton Mangoma, who wrote a letter to Tsvangirai in January $2014.3^{35}$ The Mangoma letter resulted in him being attacked physically by some of the MDC supporters who were against the idea of leadership renewal. The MDC President reacted by suspending Elton Mangoma and a few other members, which some have referred to as purges done to eliminate any kind of opposition to his leadership.

The purges led to more infighting in the public arena where the two camps, one aligned to Morgan Tsvangirai and the other to Tendai Biti presented public shows suspending others from the party structures and countering each other's actions and decision until they referred the matter to the Speaker of Parliament. The Speaker of Parliament advised the two factions to refer to competent courts since it was outside his jurisdiction because it was an internal squabble. At some point, Tendai Biti reportedly acknowledged that the ZANU PF manifesto was better than the MDC manifesto pointing to why the MDC lost the elections. To some this might sound out of tune for a party Secretary General to make such pronouncements yet his post then made him more responsible for the direction that the party takes more than any other person. The eventual split that resulted in two MDC-T factions points to inherent differences that existed between members of the MDC-T even through the GNU period. Such differences account for cases like the reshuffling of the MDC-T part of cabinet in 2010.

The two factions have since been levelling allegations and insults upon each other, with the Morgan Tsvangirai faction alleging that the Tendai Biti side is being used by the Western world which is bent on removal of Morgan Tsvangirai. The same allegations that the Western world was accused of during the formation stages and early years of the MDC, seeking the removal of Robert Mugabe from power. These allegations, some have argued point to the suspicion that Morgan Tsvangirai is a dictator within as witnessed by some of his acts in the past like imposing candidates on constituencies where he had clashes with some party members, a point in case being the imposition of Sengweni in the Redcliffe constituency in the March 2008 Parliamentary race, where Morgan Tsvangirai had personal differences with former Midlands North Treasurer Aaron Chinhara and therefore decided to divide votes at the cost of the struggle. Such cases of putting personality clashes ahead of what is good for the struggle they were into against their inherent rivals ZANU PF. Most views shared on the recent MDC-T split have accused the party of failing to focus on public good, instead they let personal clashes override and destroy the people 'struggle. As it is now, the MDC-T has lost relevance and risk being overtaken by events.

\subsection{MDC-N Scenario}

During the NGU term, leadership change in the MDC-M camp at their congress rendered Arthur Mutambara, the Deputy Prime Minister irrelevant to Zimbabwean politics. The new Party president Welshman Ncube tried to subvert his authority in the GNU by calling for his removal but the President denied that move and insisted that he remains the Deputy Prime Minister as one of the Principals despite the leadership change in their camp. As soon as the GNU period lapsed, nothing much was heard of Mutambara and the MDC-M, they lost relevance and were overtaken by the events of the 2013 elections where they failed to secure a single contested seat in Parliament ${ }^{36}$ dominated by the ZANU PF party.

\section{Conclusion}

At the end of the GNU in 2013, the parties returned to their respective camps, resuming their inherent divisions within the parties and the traditional enmity between the main parties. However, the MDC-T faced a serious crisis as their divisions led to a split while ZANU PF continued to conceal its differences and divisions. The MDC-M, now MDC-N in a way was

35 Tichaona Zindoga (2014) How the Opposition MDC-T imploded New African June 2014 Issue 540 IC Publications, London. p. $52-53$

${ }_{36}$ Zimbabwe Situation 13 September 2013, MDC ‘s Ncube Plotting Victory in 2018 www.zimbabwesituation.com 
overtaken by events and was rendered irrelevant as not much has been heard of it in the post GNU scenario. Negotiated governments therefore, work to momentarily achieve the much needed peace for co-existence and economic progression, on one hand. On the other hand however, infighting will remain and parties continue to attack each other or even infiltrate each other for the ultimate goal of total destruction of the opposing force. All having been said, power sharing helps in peaceful resolution of differences as witnessed in Zimbabwe where declared enemies managed to sit face to face to discuss national issues and find possible solutions to them. The country is however in need of economic rescuing since it is faced with deflation at the moment, which is basically about a decrease in the price of goods and services mainly due to shortage of money as consumers are cash stripped.

\section{References}

Kadima, D. (2006). The Politics of Party Coalitions in Africa. Auckland Park: EISA and Konrad Adenauer-Stiftung.

Masunungure, E.V. (2009) Defying the Winds of Change: Zimbabwe's 2008 Elections. Harare: Weaver Press and Konrad Adenauer Foundation.

Raftopoulos, B. (2013). The Hard Road to Reform: the Politics of Zimbabwe's Global Political Agreement. Harare: Weaver Press.

Sachikonye, L. (2011). When a State Turns on its Citizens: Institutionalised Violence and Political Culture. Aukland Park: Jacana Media (Pty) Ltd.

Africa Briefing, (2009). Zimbabwe: Engaging the Inclusive Government. Number 59 of April 2009.

Bertelsmann Stiftung (2014). BTI 2014 - Zimbabwe Country Report. Gutersloh: Bertelsmann Stiftung.

Chigora, P. and Guzura, T. (2011). The Politics of the Government of National Unity (GNU) and Power Sharing in Zimbabwe: Challenges and Prospects for Democracy. African Journal of History and Culture, Volume 3 number 2.

Fayemi, A. K. (2009). Towards an African Theory of Democracy: Thought and Practice. A Journal of the Philosophical Association of Kenya (PAK).

LeVan, A.C (2011). Power Sharing and Inclusive Politics in Africa's Uncertain Democracies. Governance: International Journal of Policy, Administration and Institutions, Volume 24 number 1.

Maroleng, C. (2003). Prospects for Political Transition in Zimbabwe. African Security Analysis Programme, Closed Round Table Report, Institute of Security Studies (14 May 2003).

Masunungure, E.V. (2009). Zimbabwe's Power Sharing Agreement Paper presented at a workshop on The Consequences of Political Inclusion in Africa 24-25 April 2009, American University, Washington D.C.

Mapuva, J. (2013). Governments of National Unity (GNUs) and the Preponderance of the Incumbency: Case of Kenya and Zimbabwe. International Journal of Political Science and Development, Volume 1 Number 3.

Maruta, S.et al (2013). A Review of Zimbabwe's Global Political Agreement. Southern Peace Review Journal, Volume 2 Number 1 , Harare: Southern Institute of Peace Building and Development.

Nhede, T. (2012). The Government of National Unity in Zimbabwe: Challenges and Obstacles to Public Administration. African Journal of Public Affairs, Volume 5 number 3.

Spears, I.S (2000). Understanding Inclusive Peace Agreements in Africa: The Problems of Sharing Power. Third World Quarterly, Volume 21 number 1.

The Sunday Mail (2014). Women Refuse to Listen to Listen to Evil Machinations: President (17 August 2014).

Zimbabwe Situation (2013). MDC's Ncube Plotting Victory in 2018 www.zimbabwesituation.com. (13 September 2013)

Zindoga, T. (2014). How the Opposition MDC-T Imploded. New African June 2014 Issue 540, London: IC Publications. 